特 集

\title{
磁界共振結合における効率と磁束
}

\section{Efficiency and Magnetic Flux in Magnetic Resonant Coupling}

居村 岳広 ${ }^{* 1}$ (非会員)

Takehiro IMURA

\begin{abstract}
Typically, the difference between electromagnetic induction and magnetic resonant coupling is ambiguous. However, these two technologies are seamlessly connected. In this paper, the superiority of magnetic resonant coupling over electromagnetic induction, as well as the magnetic flux distinctive features, are demonstrated and discussed by comparing four circuit topologies. It is shown that only the S-S topology can achieve both high power and maximum efficiency and that the magnetic flux possesses unique characteristics.

Keywords: magnetic resonant coupling, electromagnetic induction, wireless power transfer
\end{abstract}

（2016 年 8 月 23 日受付）

\section{1 まえがき}

2007 年に新しいワイヤレス電力伝送方式として MIT から磁界共振結合（磁界共鳴）と電界共振結合 (電界共鳴）が発表された $[1,2]$ 。電界共振結合 $[3,4]$ も同様に議論できるが，本稿では磁界の結合を取り 上げる。磁界共振結合に関しては，2 つの共振コイ ル間において，エアギャップ $1 \mathrm{~m}$ で効率約 $90 \%$ ，ま た, エアギャップ $2 \mathrm{~m}$ で効率約 45〜 50\%かつ $60 \mathrm{~W}$ を ワイヤレスで電力伝送出来ることが示された。実験 に使用した送電と受電用の共振コイルは半径 $30 \mathrm{~cm}$, 5.25 巻，周波数は約 $10 \mathrm{MHz}$ である。

磁界共振結合に関しては，これまでに，音叉による 説明, 現象の解明 $[5,6] や$, 等価回路化の提案 $[4,7-9] や$ バンドパス理論を用いた解釈 $[10,11], k Q$ 積による解 釈 $[12,13]$, 効率最大化の提案[14]動作周波数の拡大 [15], 中継コイル $[16,17]$ 複数負荷への給電 $[18]$ など多くの発 表がある。この技術は，様々な応用が期待され，電気 自動車へのワイヤレス給電 $[19,20]$ や走行中の電気自 動車へのワイヤレス給電[21], 家庭内の家電へのワイ ヤレス給電[22], 電車への給電[23-26]など, 様々な検 討がされている。

一方で，理論背景に関しては，先に述べたように， 音叉を用いた説明や，結合モード理論を用いた説明

連絡先：居村 岳広, $\bar{\top} 277-8561$ 千葉県柏市柏の葉 5-1-5, 東京大学大学院工学系研究科電気系工学専攻,

e-mail: imura@hori.k.u-tokyo.ac.jp

*1 東京大学
であり $[1,2]$ かつ，動作周波数も当時は多くの人にと ってなじみのない $10 \mathrm{MHz}$ で説明した故に，当時は， この現象が電磁誘導の一種かどうかということ自体 が最初の発表当初より議論を呼んでいた[27]。この 電磁誘導方式と磁界共振結合方式の相違について は，近年では，磁界共振結合の現象説明や，等価回 路表現などの研究の成果もあり，電磁誘導方式の回 路条件を絞ったものが磁界共振結合方式であるとい う認識が広がる中[7-10，28，29]，筆者らは文献[30] で，4 つの共振条件を比べることで明確に磁界共振 結合が電磁誘導の一種であることを示した。

そこで，本稿では，共振がない従来の電磁誘導方 式から，共振を上手に利用した磁界共振結合方式ま でに遷移する振る舞いを漏れなく示す事により，大 エアギャップ時の磁界共振結合の優位性について示 し，その時の磁束のふるまいについて述べる。

\section{2 従来の電磁誘導と磁界共振結合}

従来の電磁誘導は, 1 次側共振もしくは 2 次側共振 が主に採用されていた。その場合，大きなエアギャッ プに電力を送る場合, 電力と効率のどちらかのみ良く なるだけであり, 1 次側共振では効率が悪く, 2 次側共 振では電力がほとんど受け取れないため現実的には使 いものにならなかった。これらに対し，1 次側共振と 2 次側共振をもつ磁界共振結合は大電力かつ高効率を大 エアギャップでも実現できる。その一端がわかる写真 を Fig.に示す。 


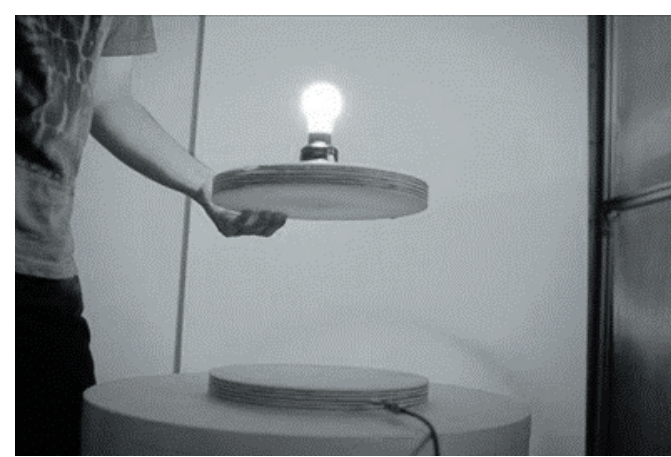

Fig. 1 Demonstration of magnetic resonant coupling.

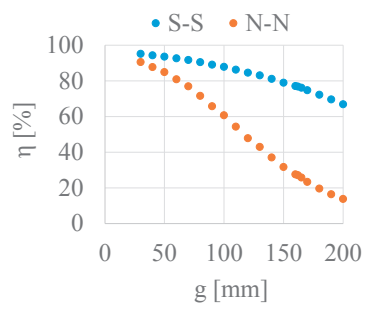

(a) Efficiency

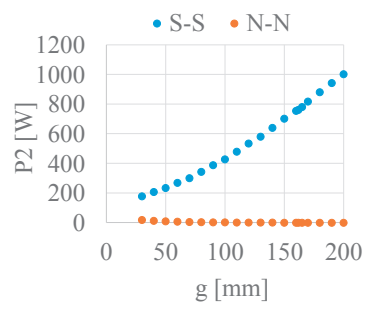

(b) Power
Fig. 2 Comparison of typical electromagnetic induction and magnetic resonant coupling.

Table 1 Circuit and coil parameters.

\begin{tabular}{|c|c|c|c|c|c|c|c|}
\hline$m$ & Cal & Exp. & $m$ & Cal & Exp. & & Exp. \\
\hline$f[\mathrm{kH} z]$ & 100.0 & 100.0 & $C_{1}[\mathrm{nF}]$ & 15.9 & 15.9 & Outer radius [mm] & 300 \\
\hline$L_{1}[\mathrm{uH}]$ & 159.2 & 158.7 & $C_{2}[n F]$ & 15.9 & 15.9 & Inner radius [mm] & 100 \\
\hline$L_{2}[\mathrm{vH}]$ & 159.2 & 159.2 & $r_{1}[\Omega]$ & 1.3 & 1.4 & turns & 27.5 \\
\hline$L_{m}[\mathrm{uH}]$ & 15.9 & 15.9 & $r_{2}[\Omega]$ & 1.3 & 1.3 & $a[\mathrm{~mm}]$ & 2 \\
\hline$k[-]$ & 0.10 & 0.10 & $Q_{1}[-]$ & 75.6 & 72.6 & $s[\mathrm{~mm}]$ & 2 \\
\hline
\end{tabular}

まず，どの程度，磁界共振結合 $(\mathrm{S}-\mathrm{S})$ と従来の電磁 誘導（N-N）で，効率と電力が異なるのかを定量的に 示すために Fig. 2 にグラフを示す。エアギャップが近 い時には，効率 $\eta$ はほぼ同じであるが，大エアギャッ プと言われる，半径を超えるエアギャップである $150 \mathrm{~mm}$ 位になると, 効率 $\eta$ の差は明らかである。更に 受電電力 $P_{2}$ に関しては, 圧倒的に磁界共振結合 $(\mathrm{S}-\mathrm{S})$ が上回っている。この様に，大きなエアギャップの時 にも高効率と大電力を実現できるのが磁界共振結合

(S-S) の特徴である。

Fig. 2 で使用した回路パラメータとコイルの寸法を Table 1 に示す。 $a$ は導線の太さ, $s$ は導線間の距離で ある。Fig. 3 に送受電コイル写真を示す。実測よりエ アギャップ $g=16.2 \mathrm{~cm}$ の時に結合係数 $k=0.10$ となる。 $k=1$ に比べ $1 / 10$ の值を設定することで，大エアギャ ップ時の特性を確認する事を目的としている。以後, このパラメータを使用する。

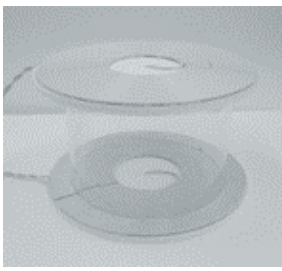

Fig. 3 Transmitting and receiving coils.

\section{3 電磁誘導と磁界共振結合の式の導出[30]}

共振の有無で分類した，磁界での結合の 4 回路方 式を Fig. 4 に示す。全て大きな分類としては電磁誘 導方式である。1 次側と 2 次側に共振がない非共振 回路は N-N (N: Non-Resonant)と呼び，2 次側のみに 共振用コンデンサがある回路は 2 次側共振回路 N-S(S: Series), 1 次側のみに共振用コンデンサがあ る回路は 1 次側共振回路 S-N, 1 次側と 2 次側に共 振コンデンサがある回路は電磁誘導の中でも特別に 磁界共振結合 S-S と呼ぶ。S-P（P: Parallel）は S-S の変形として同様の議論ができ，磁界共振結合に含 まれる[30]。

S-S 方式の等価回路を Fig. 5 に示す。これは, Fig. 4 (d)に示した S-S 回路の T 型等価回路である。一般 的な回路では, $-L_{m}$ を一体化して書かれることが多い ので, 分離して描くこのタイプを拡張型としている。 N-N から S-S への推移をこの後確認するが, その時, 理論的には S-S 回路から考えると理解し易い。S-S 回路においては式(1)の様に 1 次側のインピーダンス の虚数成分，つまり，リアクタンスは $X_{1}$ であり，同 様に，式(2)の様に 2 次側のリアクタンスは $X_{2}$ であ る。各々， $L_{1}$ と $C_{1}$ もしく $L_{2}$ と $C_{2}$ で作られる。ま ず，コイルは同じなので， $\omega L_{1}=\omega L_{2}=100 \Omega$ は変わら ない。次に，共振コンデンサを考える。 $C_{1}$ を無限大 にした場合，1 次側にコンデンサはないことになり， つまり，導通状態になり，式(1)は $X_{1}=\omega L_{1}$ になる。 同様に， $C_{2}$ を無限大にした場合，式(2)は $X_{2}=\omega L_{2}$ に なる。両方の共振コンデンサを無限大にした場合，

$\mathrm{N}-\mathrm{N}$ 回路になる。そこから， $C_{1}$ や $C_{2}$ の共振コンデ ンサの值を小さくしていき，絶縁状態に近づけて行 くと， N-N から S-S へと推移することになる。例え ば，N-N から N-S を経由して，S-S になるときには， はじめに $C_{2}$ を挿入し， $X_{2}=0$ として，次に $C_{1}$ を挿入 し， $X_{1}=0$ とする手順となる。

$X_{1}=\omega L_{1}-\frac{1}{\omega C_{1}}$ 


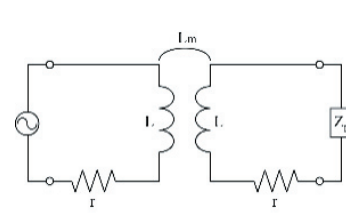

(a) $\mathrm{N}-\mathrm{N}$

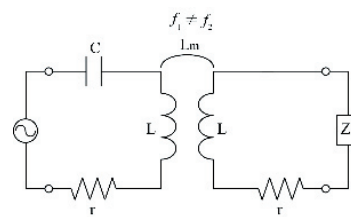

(c) S-N

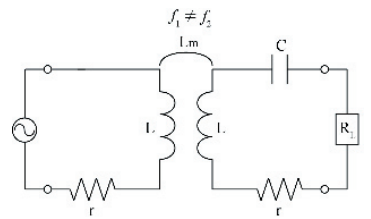

(b) N-S

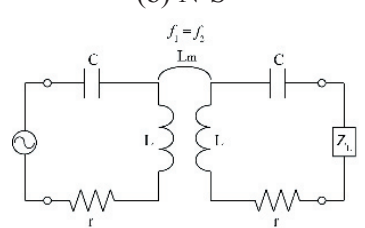

(d) S-S
Fig. 4 Resonance types of wireless power transfer using magnetic coupling.

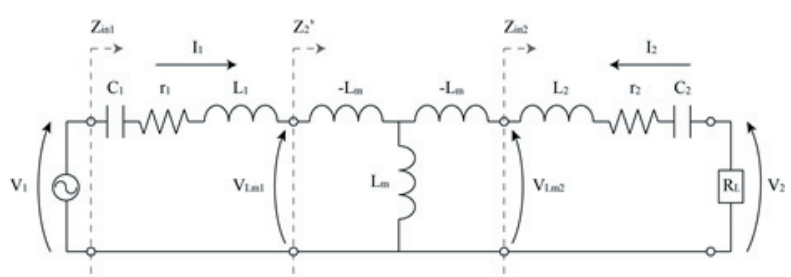

Fig. 5 S-S T-type equivalent circuit.

$X_{2}=\omega L_{2}-\frac{1}{\omega C_{2}}$

$\mathrm{N}-\mathrm{N}$ から S-S への推移を考える一般式を求める。 まず，一般的な効率の式は，式(3)となる。各々，入 力電力 $P_{1}, 1$ 次側内部抵抗による消費電力 $P_{r 1}, 2$ 次 側内部抵抗による消費電力 $P_{r 2}$, 負荷での消費電力 $P_{2}$ である。

$$
\eta=\frac{P_{2}}{P_{1}}=\frac{P_{2}}{P_{r 1}+P_{r 2}+P_{2}}
$$

次に, 1 次側の電圧と 2 次側の電圧の式(4), (5)は 式(6), (7)となるので, 電流 $I_{1}, I_{2}$ が式(8), (9)の様に 求まる。

$$
\begin{aligned}
& V_{1}=V_{L 1}+V_{C 1}+V_{r 1}+V_{L m 1} \\
& 0=V_{L 2}+V_{C 2}+V_{r 2}+V_{2}+V_{L m 2} \\
& V_{1}=j \omega L_{1} I_{1}+\frac{1}{j \omega C_{1}} I_{1}+I_{1} r_{1}+j \omega L_{m} I_{2} \\
& 0=j \omega L_{2} I_{2}+\frac{1}{j \omega C_{2}} I_{2}+I_{2} r_{2}-I_{2} R_{L}+j \omega L_{m} I_{1} \\
& I_{1}=\frac{r_{2}+R_{L}+j\left(\omega L_{2}-\frac{1}{\omega C_{2}}\right)}{\left\{I_{1}+j\left(\omega L_{1}-\frac{1}{\omega C_{1}}\right)\right)\left\{I_{2}+R_{L}+j\left(\omega L_{2}-\frac{1}{\omega C_{2}}\right)\right\}+\omega^{2} L_{m}^{2}} V_{1} \\
& I_{2}=-\frac{j \omega L_{m}}{\left\{I_{1}+j\left(\omega L_{1}-\frac{1}{\omega C_{1}}\right)\right\}\left\{I_{2}+R_{L}+j\left(\omega L_{2}-\frac{1}{\omega C_{2}}\right)\right\}+\omega^{2} L_{m}^{2}} V_{1}
\end{aligned}
$$

また， $I_{1}$ と $I_{2}$ の比率は式(10)で表される。

$$
\frac{I_{1}}{-I_{2}}=\frac{r_{2}+R_{L}+j\left(\omega L_{2}-\frac{1}{\omega C_{2}}\right)}{j \omega L_{m}}
$$

次に，効率について考察する。共振条件を適応しな い効率の式などを求める。まず，共振条件を使用して いない式(8), (9)より，電力比の式(11)と効率の式(12) が求まる。

$$
P_{r 1}: P_{r 2}: P_{2}=\left\{\left(r_{2}+R_{L}\right)^{2}+\left(\omega L_{2}-\frac{1}{\omega C_{2}}\right)^{2}\right\} r_{1}:\left(\omega L_{m}\right)^{2} r_{2}:\left(\omega L_{m}\right)^{2} R_{L}
$$

$$
\eta=\frac{\left(\omega L_{m}\right)^{2} R_{L}}{\left\{\left(r_{2}+R_{L}\right)^{2}+\left(\omega L_{2}-\frac{1}{\omega C_{2}}\right)^{2}\right\} r_{1}+\left(\omega L_{m}\right)^{2} r_{2}+\left(\omega L_{m}\right)^{2} R_{L}}
$$

式(12)から最大効率となる最適負荷の条件式(13)が 得られる。これを式(12)に代入すれば，最大効率が得 られる。

$$
R_{\text {Lopt }}=\sqrt{r_{2}^{2}+\frac{r_{2}\left(\omega L_{m}\right)^{2}}{r_{1}}+\left(\omega L_{2}-\frac{1}{\omega C_{2}}\right)^{2}}
$$

上記式を使用し, $C_{1}$ と $C_{2}$ を変化させることで, N-N, N-S，S-N，S-S だけでなく，その推移も計算すること が可能である。1 次側と 2 次側の共振周波数を同じに すると，この時の共振角周波数は式(14)となる。

$$
\omega_{0}=\omega_{1}=\sqrt{\frac{1}{L_{1} C_{1}}}=\omega_{2}=\sqrt{\frac{1}{L_{2} C_{2}}}
$$

これらの共振条件の式を満たすと， $I_{1}$ と $I_{2}$ の比率は 式(15)で表される。

$$
\frac{I_{1}}{-I_{2}}=\frac{r_{2}+R_{L}}{j \omega L_{m}}
$$

\section{4 磁界共振結合の優位性 (N-N から $\mathrm{S}-\mathrm{S}$ への遷 移) [31]}

実際に大きなエアギャップといわれる時は， $k=0.1$ を下回る領域が多いが，説明の都合上，はじめに $k=0.5$ の時のグラフを使用して説明する。参考までに エアギャップ $g$ と結合係数 $k$ のグラフを Fig. 6 に示 于。

$k=0.5$ の時の送電電力 $P_{1}$, 受電電力 $P_{2}$, 一次側力 率 $\cos \theta_{Z i n 1}$, 効率 $\eta$, 二次側力率 $\cos \theta_{Z i n 2}$ について $\mathrm{N}-\mathrm{N}$ から S-S への推移を一括で Fig. 7 に示す。図の右端 $X_{1}=100 \Omega$ の時が $C_{1}$ が無いとき, 図の上端 $X_{2}=100 \Omega$ の時が $C_{2}$ が無いときに相当する。

各々の図における $\mathrm{Z}$ 軸は, $P_{1}, P_{2}, \cos \theta_{Z i n 1}, \eta, \cos \theta_{Z i n 2}$ に対応している。この時の負荷条件は最大効率となる。 


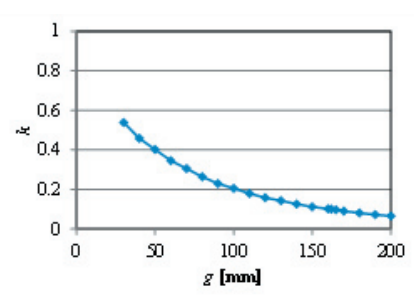

Fig. 6 Air gap $g$ and coupling coefficient $k$.

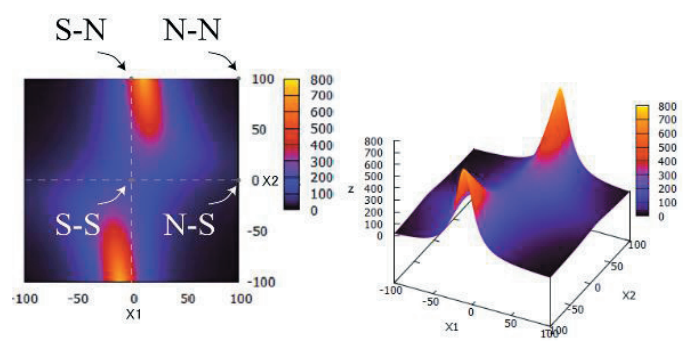

(a) Transmitting power $P_{1}$
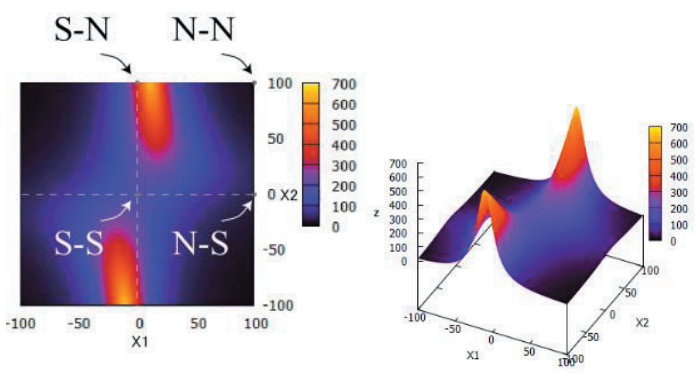

(b) Receiving power $P_{2}$
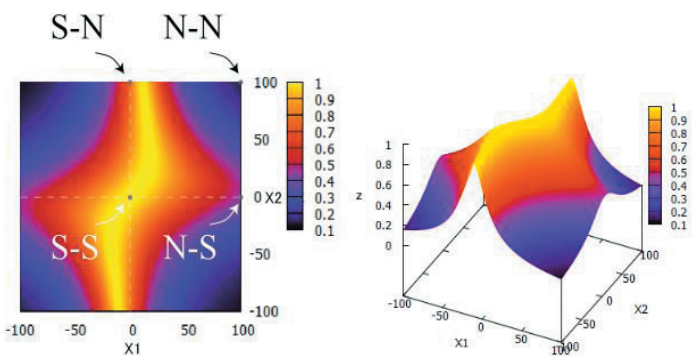

(c) Primary side power factor $\cos \theta_{Z i n 1}$

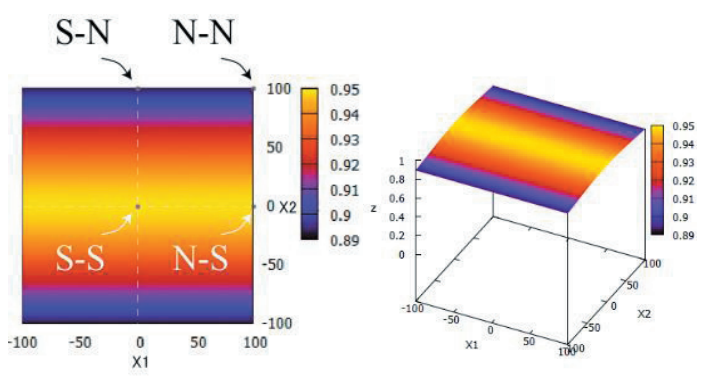

(d) Efficiency $\eta$

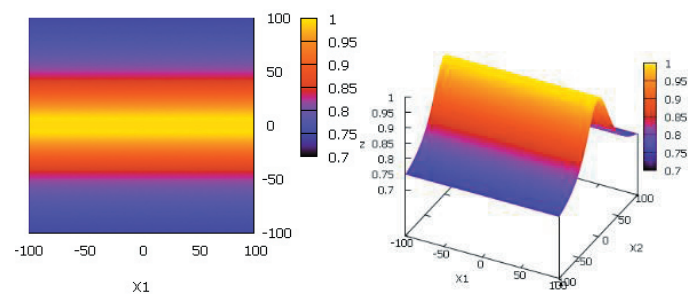

(e) Secondary side power factor $\cos \theta_{\operatorname{Zin} 2}$

Fig. 7 3D map of N-N, N-S, S-N and S-S, $k=0.5$.
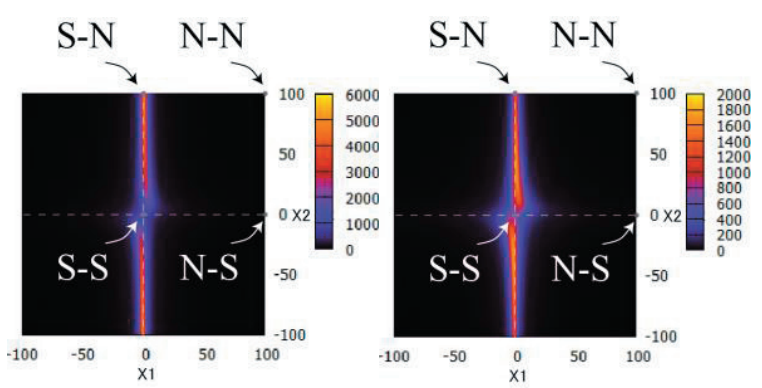

(a) Transmitting power $P_{1}$

(b) Receiving power $P_{2}$
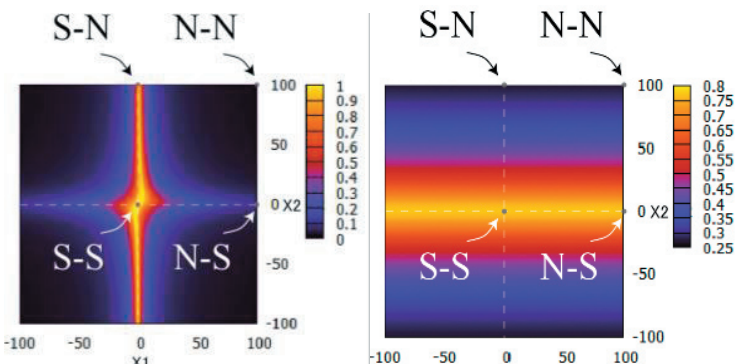

(c) Primary side power factor $\cos \theta_{Z i n 1}$ (d) Efficiency $\eta$

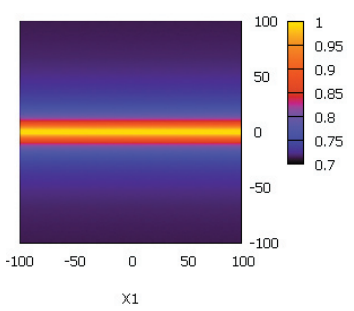

(e) Secondary side power factor $\cos \theta_{\operatorname{Zin} 2}$

Fig. 8 3D map of N-N, N-S, S-N and S-S, $k=0.1$.

同様の議論が，大エアギャップである $k=0.1$ にし たときにも言える。繰り返しの文章となるため，本 稿では, Fig. 8 に図のみ示す。

文献[1]などの発表は，ここの S-S の動作点で使用 することをピンポイント発表したことになる。当初 は, 結合モード理論を用いて説明し, 動作周波数も 当時は多くの人がなじみのない $10 \mathrm{MHz}$ で説明した ため, 電磁誘導の条件を絞ったものが磁界共振結合 であるというコンセンサスを得るのが遅れたことに なる。 


\section{5 電磁誘導と磁気共振結合の磁束の比較}

1 次側電流と 2 次側電流の比は, S-S と N-S は式(16) となり， S-N と N-N は式(17)となる。

$$
\begin{aligned}
& \frac{I_{1}}{I_{2}}=\frac{I_{2}+R_{L}}{j \omega L_{m}} \\
& \frac{I_{1}}{I_{2}}=\frac{I_{2}+R_{L}+j \omega L_{2}}{j \omega L_{m}}
\end{aligned}
$$

また, 磁束 $\Phi$ とインダクタンス $L$ と電流 $I$ との関係 は, $\Phi=L I$ なので, 磁束は電流に比例することを考慮 すると磁束の分布も理解できる。

$\mathrm{N}-\mathrm{N}$ は $I_{1}$ も $I_{2}$ もともに小さく, 1 次側と 2 次側のコ イルに発生する磁界が小さい。また, 式(17)に示した 比を保持するので, 1 次側の方が電流も磁束も大きく なる。1 次側の電力が大きく, 2 次側の電力が小さく, 効率は低い。

$\mathrm{S}-\mathrm{N}$ は $I_{1}$ も $I_{2}$ も大きくなり, 1 次側と 2 次側のコイ ルに発生する磁界が大きくなる。しかし, 式(17)に示 した比を保持したままなので, N-N と同様に 1 次側の 方が電流も磁束も大きくなる。それ故に，1 次側の電 力が大きく, 2 次側の電力が小さく, 効率は低いまま である。

N-S は N-N と比べると 2 次側での共振があるために, $\mathrm{N}-\mathrm{N}$ の時に比べ 2 次側での電流が増える。N-N の時に 比べると， $I_{2}$ の值が $I_{1}$ に対して大きくなる。ただし, 式(16)に示した比を保持し, 最適負荷の時には, $I_{1} \fallingdotseq I_{2}$ なので[30], 1 次側と 2 次側の電流がほぼ等しい状況ま で増えるという表現が正しい。よって, 2 次側コイル の磁束も増え, 1 次側コイルの磁束と同じくらいまで になる。効率は高いが, そもそも電流が 1 次側も 2 次 側もほとんど流れないので, 受電電力は小さい。

S-S は N-N と比べると, 2 次側と 1 次側の共振があ り, 1 次側に流れる電流も 2 次側に流れる電流も大き くなる。その比は, 式(16)に示した比を保持し, N-S と同様に, 最適負荷の時には, $I_{1} \fallingdotseq I_{2}$ なので, 1 次側と 2 次側の電流がほぼ等しい状況まで増える。よって, 2 次側コイルの磁束も増え, 1 次側コイルの磁束と同じ くらいまでになる。効率は高く, 受電電力も大きい。

以上を踏まえ, 磁束の分布についてまとめると, N-N は 1 次側の磁束が大きく, 2 次側の磁束はわずかとな る。また, 他卜ポロジーに比へ磁束自体の振幅も小さ い。N-S は 1 次側と 2 次側の磁束が同じくらいになる が, 他トポロジーに比べ磁束自体の振幅は小さくなる。 $\mathrm{S}-\mathrm{N}$ は 1 次側と 2 次側の磁束はともに大きくなる

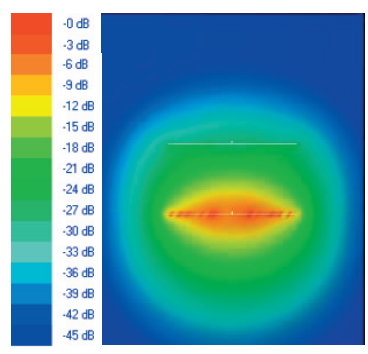

(a) N-N

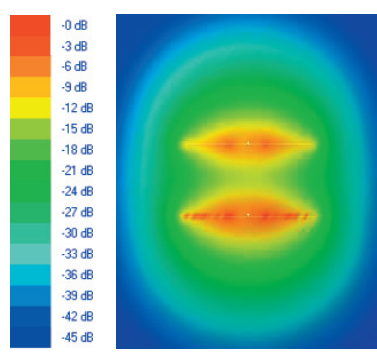

(c) N-S

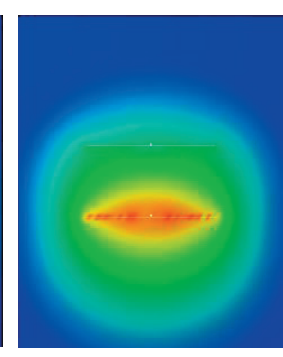

(b) S-N

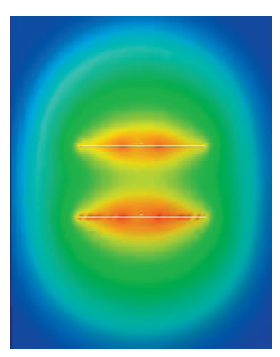

(d) S-S
Fig. 9 Magnetic flux.

が，1 次側の方が大きくなり，他卜ポロジーに比べ磁 束自体の振幅も大きくなる。S-S は 1 次側と 2 次側の 磁束が同じくらいになり, 他卜ポロジーに比心゙磁束自 体の振幅も大きくなる。

電磁界解析で得られた磁界強度を Fig. 9 に示す。最 大の磁界強度はN-Nでは 8.3[A/m], S-N では 844.5[A/m], N-S では 8.2[A/m], S-S では 96.6[A/m]であり, 各々そ の值で規格化されている。Fig. 9 からも, 磁界の強弱 がこれまで述べてきた通りであることがわかる。

つまり, N-N と S-N の時は 1 次側の磁束が大きい。 但し, N-N は磁束が小さく, S-N は磁束が大きい。そ して, N-S と S-S の時は, 最適負荷の時には, $I_{1} \fallingdotseq I_{2}$ という特徵を持つので[30], 1 次側と 2 次側の磁束がほ ぼ等しくなる。但し, N-S は磁束が小さく, S-S は磁 束が大きい。

\section{6 まとめ}

磁界共振結合と従来の電磁誘導を 4 つの回路卜ポロ ジーを用いて比較した。大きなエアギャップにおいて, 大電力かつ高効率が磁界共振結合の回路卜ポロジーの 時のみにおいて達成できることを示した。また，この 時の磁束の分布は, 1 次側と 2 次側の電流比によって, $\mathrm{N}-\mathrm{N}$ と S-N では 1 次側に磁束が集中し, N-S と S-S で はほぼ均等に 1 次側と 2 次側に磁束が分布しているこ とを示した。 


\section{謝辞}

本研究の一部は JSPS 科研費 25709020 の助成を受け たものです。

\section{参考文献}

[1] André Kurs, et al., Wireless Power Transfer via Strongly Coupled Magnetic Resonances, Science Express, Vol. 317, No. 5834, pp. 83-86, 2007.

[2] Aristeidis Karalis, et al., Efficient wireless non-radiative mid-range energy transfer, Annals of Physics, Vol. 323, pp. 34-48, 2008

[3] 居村岳広, 内田利之, 堀洋一, 非接触電力伝送用メア ンダラインアンテナの提案, 電子通信情報学会ソサイ エティ大会, B-9-1, p140, 2008.

[4] 居村岳広, 堀洋一, 電磁界共振結合による伝送技術, 電 気学会誌, Vol. 129, No. 7, pp. 414-417, 2009.

[5] 居村岳広, 岡部浩之, 内田利之, 堀洋一, 共振時の電磁 界結合を利用した位置ずれに強いワイヤレス電力伝送 一磁界型アンテナと電界型アンテナー, 電学論 D, Vol. 130, No. 1, pp. 76-83, 2010.

[6] Qiang Chen, Long Li and Kunio Sawaya, Numerical Analysis on Transmission Efficiency of Evanescent Resonant Coupling Wireless Power Transfer System, IEEE Trans. Antennas Propag., Vol. 58, No. 5, pp. 1751-1758, 2010.

[7] 居村岳広, 内田利之, 堀洋一, 近傍界用磁界アンテナの 共振を利用した高効率電力伝送の解析と実験一基本特 性と位置ずれ特性一, 平 20 年度電気学会産業応用部門 大会, Vol. II, 2-62, pp. 539-542, 2008.

[8] 平山裕, 小澤俊之, 平岩洋介, 菊間信良, and 榊原久二男, 無線電力伝送の共鳴モードと等価回路表現, 電子情報通 信学会技術研究報告. A・P, アンテナ・伝播, Vol. 109, No. 183, pp. 35-40, 2009.

[9] 居村岳広, 岡部浩之, 内田利之, 堀洋一, 等価回路から 見た非接触電力伝送の磁界結合と電界結合に関する研 究 一共振時の電磁界結合を利用したワイヤレス電力伝 送一,電学論D, Vol. 130, No. 1, pp. 84-92, 2010.

[10]粟井 郁雄, 共鳴型ワイヤレス電力伝送の新しい理論, 電 学論 C, Vol. 130, No. 6, pp.966-971, 2010.

[11]粟井 郁雄, 磁気結合共振器型ワイヤレス給電システム の BPF 理論による設計法, 電気学会論文誌. C, Vol. 130, No. 12, pp. 2192-2197, 2010.

[12]居村 岳広, 電磁界共振結合, パワーエレクトロニクス ハンドブック, 1 編 11 章 5.2 節, pp. 195-198, オーム 社, 2010 .

[13]遠井 敬大，金子 裕良，阿部 茂，非接触給電の最大効 率の結合係数 $\mathrm{k}$ とコイルの Q による表現, 電気学会論文 誌, Vol. 132, No. 1, pp. 123-124, 2012.

[14]居村岳広，堀洋一，等価回路から見た磁界共振結合にお けるワイヤレス電力伝送距離と効率の限界值に関する 研究, 電学論D, Vol. 130, No. 10, pp. 1169-1174, 2010.

[15]居村岳広, 岡部浩之, 堀洋一, $\mathrm{kHz} \sim \mathrm{MHz} \sim \mathrm{GHz}$ におけ る磁界共振結合によるワイヤレス電力伝送用アンテナ
の提案, 電子情報通信学会総合大会講演論文集, S-24-S25, BS-9-5, 2010.

[16]居村 岳広, 磁界共振結合のワイヤレス電力伝送におけ る中継アンテナの等価回路化, 電学論 D, Vol. 131, No. 12, pp. 1373-1382, 2011.

[17] Shimada, A. , Ito, Y. , Uehara, H. and Ohira, T., Effect of hop counts on power division ratio in multi-hop power transfer via magnetic resonance, Wireless Power Transfer (WPT), 2013 IEEE , pp. 179,182, 15-16, 2013.

[18]Benjamin L. Cannon,James F. Hoburg,Daniel D. Stancil and Seth Copen Goldstein, Magnetic Resonant Coupling As a Potential Means for Wireless Power Transfer to Multiple Small Receivers, IEEE TRANSACTIONS ON POWER ELECTRONICS, Vol. 24, No. 7, 1819-1825, 2009.

[19] Yukio Yokoi, Akihiko Taniya, Masaki Horiuchi and Shigeru Kobayashi, Development of kWClass Wireless Power Transmission System for EV Using Magnetic Resonant Method, 1st International Electric Vehicle Technology Conference 2011, 20117267, pp.1-6.

[20]居村岳広,加藤昌樹, 堀洋一, 磁界共鳴による EV 用ワイ ヤレス給電技術，まぐね, Vol.9, No. 3, pp. 105-110, 2014.

[21]加藤昌樹, 居村岳広, 堀洋一, 走行中ワイヤレス給 電用アンテナに関する受電位置と効率に関する検討, 平成 24 年電気学会産業応用部門大会, Vol. 2, pp. 219-222, 2012.

[22]庄木裕樹， ワイヤレス電力伝送の技術動向・課題と実 用化に向けた取り組み，信学技報，WPT2010-07, 2010.

[23] 北澤智志, 近藤圭一郎, 柏木隆行, 非接触給電システム の電力変換回路におけるコイル位置ずれ時の定電力伝 送制御法とその特性, 電気学会論文誌 D, Vol. 133-D, No. 5, pp. 518-525, 2013.

[24]山本浩平, 丸山貴嗣, 近藤圭一郎, 柏木隆行, 大容量非 接触給電トランスの無効電力を考慮した設計法, 電気学 会論文誌 D, Vol. 133, No. 3, pp. 378-385, 2013.

[25]下出大輔, 村井敏昭, 澤田理, 鉄道用非接触給電 2 次コ イルへの離散配置コアの適用, Vol. 135, No. 10, pp. 1017-1024, 2015.

[26]下出 大輔，村井 敏昭，澤田 理，試験装置を用いた鉄 道用非接触給電システムの実用化検証, 電気学会論文誌 D, Vol. 136, No. 1, pp. 37-45, 2016.

[27]居村岳広, 内田利之, 堀洋一, 非接触電力伝送における 電磁誘導と電磁界結合の統一的解釈, 電気学会自動車研 究会, VT-09-007, pp. 35-40, 2009.

[28]長塚裕一，江原夏樹，金子裕良，阿部 茂，一次直列二 次直列共振コンデンサを用いた非接触給電の給電効率, 電気学会産業灾用部門大会講演論文集, 2-27, 2009.

[29]甲斐敏祐，トロンナムチャイクライソン，電気自動車用 途における非接触充電の受電回路卜ポロジの検討, 電気 学会論文誌. D, 産業応用部門誌, Vol. 132, No. 11, pp. 1048-1054, 2012.

[30]居村岳広, 堀洋一, 電磁誘導方式と磁界共振結合方式の 統一理論, 電学論D, Vol. 135, No. 6, pp. 697-710, 2015.

[31] 居村岳広, 堀洋一, 電磁誘導における磁界共振結合の 優位性, 電子情報通信学会研究会 WPT 研究会, WPT2015-21, pp. 1-6, 2015. 